\title{
Exploring the Role of Principals in Developing Conducive Schools Environment for
}

\author{
Learning \\ * Nazish Farid, PhD Scholar \\ ** Dr. Khisro Kaleem, Assistant Professor \\ *** Dr. Nasrullah Khan, Assistant Professor
}

\begin{abstract}
A conducive environment is a vital factor affecting the quality of the teaching-learning process of Government schools. This descriptive study aims to find out the existing role and plans of the schools to make their environment more conducive. 100 public secondary school heads were randomly selected as a sample of the research. Data were collected by questionnaires from the respondents. Chi-Square test was applied to determine the existing roles of school heads who supported environment improvement. The study revealed that school heads were in majority supported to make school climate. The data identified that the principals were trying their level best to keep constant observations of the classes and monitoring the academic activities regularly which results in making instructions effective, motivating staff, regular planning, improving the academic role, and developing strong communications with parents and community. They were also trying about teacher's motivation, professional development, and teamwork. It was recommended that for the effective role of principals strong planning to monitor teaching and improve managerial practices.
\end{abstract}

Keywords: Principals Roles, Conducive, Environment, Secondary Level, Learning Introduction

The environment is one of the recent century most important elements in the teaching-learning process in general and at school level in particular. Developing such an environment at school level, which would be friendly for learners and motivational for teachers, which might be facilitative and supportive to both the learners and teachers of today. The climate of school would be conducive after the provision of all possible physical facilities, human facilities, and making the learning process more effective and compatible with the rest of the globe. In making a school effective, the principal or head of the institute role could not be neglected because making school effective and learning-friendly is not possible until and unless the practical role of the head of it.

Agosiobo (2007) stated that trained and qualified faculty, world-class school administration, effective leaders, check and balance modern teachings, and conducive learning climate. Education at the secondary level is considered the most basic phase of education for learners and the role of secondary school heads need to be more practical, impartial, balanced, cooperative, supporting and leading, to make the climate more effective and learning-friendly for both teachers and the learners', therefore, it is of more importance as compared to tertiary education.

The principal post is one of the central posts because a principal at a time would bind to work as a multidimensional role in providing better learning opportunities to the learners in his/her school. Principal communication with teachers and parents affect the learning and teaching climate more conducive and effective. The ideal communication between school and family showed that those parents who were in regular contact with schools, their kids' academic progress, and views about school excellence were more positive and the parents who were not interested in communication with schools were not. They were not that much responsive regarding their kids' issues or even progress report or diary replies. Parents were not encouraging schools about their children's academic matters and other related matters faced by them at schools. It is also identified that the attitude of the parents

\footnotetext{
* Sarhad University of Sciences and Information Technology (SUIT), Peshawar Pakistan

** Sarhad University of Sciences and Information Technology (SUIT), Peshawar Pakistan

*** Poonch University Rawalakot AJK
} 
and teachers was the main cause of school effective climate. parents were agreed about the information and news from the school offices but they were not agreed about the responses from them due to their jobs, busy daily routines and lack of interest in this particular field because they thought that the school must teach and guide their children in all related matters at their own (Khan, 2017).

The school principal is a person who works at the same time as a manager, as an administrator, as ahead, as a leader, as a finance manager, as a community mobilizer, as a good teacher, etc. he /she is looking at the academic-related activities and also at the co-curricular and social sector activities which can make the school effective and more conducive for learning. The development of education is always the main motto of the school head and that why he/she is always struggling to update his/her team as one of the best teams in academic and non-academic matters at the school level. It's essential to change the school climate to bring the executive revolution and that there will be a fundamental affiliation involving the position of the head along with directorial knowledge. A responsibility throughout assessments has happened to a hazard, institution heads required toward effort for long term climate to make educational atmosphere stronger. Furthermore, the impression of an organization head is very specific to prolong institution development. He endorses that organization heads should work for new instruction and educational processes to develop in the organization. A survey of different schools explains that to enhance teacher's morale along with student's achievement one should focus on the development of the school's climate. School heads were to be aware of their own school's climate, the ways how a low performing high school climate can be changed by new Principal and it positively influences student performance and achievement. Schools can be made effective and quality would be made by school leaders that are the key personals for continuous educational reformation and improvement (Fullan, 2002). Lyons (2012) stated that the school should be focused on the availability of class-related resources and managerial skills which pave the track for the effective school climate. The classes should be equipped with all the needed materials and facilities which would be useful for the learners and also will help teachers to explain the lesson more easily and briefly. The AV aids available for the class teachers are always helpful for both teachers and students because it not only provides a sort of practical model, charts and maps, etc, for clarity of the students but also helping teachers in getting students full attention and motivation.

\section{Research Questions}

1. What is the existing role of school heads?

2. What are the principals' plans for making the school environment conducive?

3. What recommendations the did study make for making schools more effective?

\section{Objectives of the Study}

1. To know about principals' current and plans in making school climate conducive for learning.

2. To provide practical recommendations for developing schools climate conducive.

\section{Literature Review}

The school climate can be made conducive for teaching-learning processes when it has human resources and other related facilities because in some cases only human resources cannot make school-friendly and effective unless supported by the facilitated climate and friendly environment. The climate will be best when the teachers and students both had all the education supported items and space etc (Abdul-Kareem, 2017).

The teaching at school should be according to the need and interest of the learners and also according to the demand of the time because of the learning materials and teaching strategies are not effective and the contents not upgraded will automatically lose the learners interest and will damage their career due to the outdated curricula and old teaching styles. There are many teaching styles such as project work, lecture method, cooperative learning, group activities, and online teaching etc had already brought very much change in learning mode and clarity of the student concept, learning habits, cognitive skills, motivational strategies and study climate (Healey, 2009). According to Rosenberg, (2013) learning climate of the school can be made more refine if all the factors that could make school climate effective should be addressed properly. These factors are health measures, HR care unit, curriculum department, evaluation cell, space, management, and administration units, communication plans and budget allocation, and utilization experts. 
Iqbal (2012) said that the school head has the central post at the school level, to create the climate of effective learning at schools. If the principal is committed and strong to maintain discipline and effective educational activities at schools then the rest of the staff and members will also be working for the school betterment but if the principal is not interested then the climate if the school will not be able to deliver according to the expectation s of the parents and community.

A committed principal is supposed to be calm, tolerant, positive, patient, calculating, balanced, strong, mediator, motivator, and humorous with the staff and students \& with the community members. $\mathrm{He} /$ she will keep an eye on the day to day activities of the school and should lead the matters on his own (Finn. J, 2002).

Relationships between Principals and teachers can greatly affect the school learning climate. It is also important the school and community connection should be made strong. In the views of respondents, schools were agreed that they were informing the parents and family about all school matters which included results and progress of the students (Walsh, 2005).

In a study Hall (2009) stated that at school level when the climate was not friendly, the teachers were frustrated and they were not motivated to work due to the discouraging attitude of management. They were also claimed that parents were also not cooperative about their children the poor quality of education. They were not that much responsive regarding their kids' issues or even progress report or diary replies. Parents were not encouraging schools about their children's academic matters replies and other related matters faced to them at schools. It is also identified that the attitude of the parents and teachers was the main cause of school effective climate.

The principal should work for the betterment of school and learners. The responsibility of the head should be evaluated based on students' academic progress and their cognitive abilities because if they are weak in academic performance then the school and most particularly its head is responsible and should be accountable to the community in this regard (Yost, 2008).

According to Khan N (2017) provisions of the basic and needed facilities which included administrative, human resources, physical facilities, academic, and economic categories are all the major areas that could make an effective and conducive learning environment if these are exercised and practiced by the professional team members with justice and sense of 6 responsibilities. Managers are being the leading persons have must implement the policy of the day to make learning climate more workable. Oduwaye (2011) stated that a learning climate would be conducive if all the staff, students, and community work together under the leadership of a visionary principal. They should have a strong affinity and mission to make school climate more conducive. It was also identified by the researcher that there were lacking communication between school and community about school academic matters. Study data showed that parents, due to their businesses, did not interact with the school principal. The principal contact parents about their children's performance but parents did not respond positively to resolve the issues and design collective plans for their children's improvement. It is also stated that those parents who were indifferent jobs, did not attend parents' teachers' meetings due to their job matter.

Learning environment can be made conducive when all the factors which are responsible for it including classroom setting, modern teaching, fair exams, updated teaching skills, trained teachers, upgraded syllabi, facilities like furniture, A.V aids, lighting system, ventilation, academic resources, skilled managers and ideal learning discipline, etc (Fullan, 2002) and Friedrich et al, (2010). Parents were to be involved by the principal for making school more effective and this was also supported by Alberta, (2009) \& Krestel (2017) who divided parental involvement into two groups; i.e at school and home. Parents' role at home was: assistant with their children in the study, diary checking and assigned homework, motivating them to study, motivate them for getting good marks, listen to their school's activities if any, and giving them a study-oriented atmosphere at home. Parents' role at school was: schools visit off and on, contact with the school and class teacher or principal on a weekly or monthly basis, information sharing about children's activities and performance, school results getting and responding about it to the schools (Aliade, 2008).

\section{Research Methods}

The study is descriptive. Principals' viewpoints were gathered by administering a questionnaire. 


\section{Research Tool}

A questionnaire for principals was developed to collect the required data. It was based on a 5-point Likert Scale.

Population and Sample

The sample of 100 secondary school heads was randomly selected from Khyber Pakhtunkhwa province.

Data Analysis

Table-1. Principal's Academic role.

\begin{tabular}{|c|c|c|c|c|c|c|c|c|c|}
\hline S/No & Statements & $\begin{array}{c}\text { S A } \\
f(\%)\end{array}$ & $\underset{f(\%)}{\mathrm{A}}$ & $\begin{array}{l}\text { UD } \\
f(\%)\end{array}$ & $\begin{array}{c}\text { DA } \\
f(\%)\end{array}$ & $\begin{array}{l}\text { S D } \\
f(\%)\end{array}$ & $\begin{array}{l}\text { Chi- } \\
\text { square }\end{array}$ & d.f & $\begin{array}{c}P \text { - } \\
\text { value }\end{array}$ \\
\hline 1 & $\begin{array}{l}\text { School Head is Satisfied } \\
\text { from Her Job }\end{array}$ & $\begin{array}{c}45 \\
(45 \%)\end{array}$ & $\begin{array}{c}55 \\
(55 \%)\end{array}$ & $\begin{array}{c}0 \\
(0 \%)\end{array}$ & $\begin{array}{c}0 \\
(0 \%)\end{array}$ & $\begin{array}{c}0 \\
(0 \%)\end{array}$ & 1.000 & 1 & 0.317 \\
\hline 2 & $\begin{array}{l}\text { Principal involves teachers } \\
\text { in class activities }\end{array}$ & $\begin{array}{c}40 \\
(40 \%)\end{array}$ & $\begin{array}{c}45 \\
(45 \%)\end{array}$ & $\begin{array}{c}10 \\
(10 \%)\end{array}$ & $\begin{array}{c}5 \\
(5 \%)\end{array}$ & $\begin{array}{c}0 \\
(0 \%)\end{array}$ & 83.600 & 4 & 0.000 \\
\hline 3 & Head classroom visit & $\begin{array}{c}35 \\
(35 \%)\end{array}$ & $\begin{array}{c}58 \\
(58 \%)\end{array}$ & $\begin{array}{c}0 \\
(0 \%)\end{array}$ & $\begin{array}{c}7 \\
(7 \%)\end{array}$ & $\begin{array}{c}0 \\
(0 \%)\end{array}$ & 39.140 & 2 & 0.000 \\
\hline 4 & Principal attend classes & $\begin{array}{c}33 \\
(33 \%)\end{array}$ & $\begin{array}{c}52 \\
(52 \%)\end{array}$ & $\begin{array}{c}7 \\
(7 \%)\end{array}$ & $\begin{array}{c}8 \\
(8 \%)\end{array}$ & $\begin{array}{c}0 \\
(0 \%)\end{array}$ & 56.240 & 3 & 0.000 \\
\hline 5 & She checks using AV aids & $\begin{array}{c}33 \\
(33 \%)\end{array}$ & $\begin{array}{c}47 \\
(48 \%)\end{array}$ & $\begin{array}{c}0 \\
(0 \%)\end{array}$ & $\begin{array}{c}15 \\
(15 \%)\end{array}$ & $\begin{array}{c}5 \\
(5 \%)\end{array}$ & 41.920 & 3 & 0.000 \\
\hline 6 & $\begin{array}{l}\text { Head communicate plans } \\
\text { with teachers }\end{array}$ & $\begin{array}{c}45 \\
(45 \%)\end{array}$ & $\begin{array}{c}45 \\
(45 \%)\end{array}$ & $\begin{array}{c}10 \\
(10 \%)\end{array}$ & $\begin{array}{c}0 \\
(0 \%)\end{array}$ & $\begin{array}{c}0 \\
(0 \%)\end{array}$ & 24.500 & 2 & 0.000 \\
\hline 7 & $\begin{array}{l}\text { Principal monitor exam } \\
\text { herself. }\end{array}$ & $\begin{array}{c}28 \\
(28 \%)\end{array}$ & $\begin{array}{c}46 \\
(46 \%)\end{array}$ & $\begin{array}{c}10 \\
(10 \%)\end{array}$ & $\begin{array}{c}12 \\
(12 \%)\end{array}$ & $\begin{array}{c}4 \\
(4 \%)\end{array}$ & 58.000 & 4 & 0.000 \\
\hline 8 & Head attend PTM & $\begin{array}{c}40 \\
(40 \%)\end{array}$ & $\begin{array}{c}48 \\
(48 \%)\end{array}$ & $\begin{array}{c}0 \\
(0 \%)\end{array}$ & $\begin{array}{c}6 \\
(6 \%)\end{array}$ & $\begin{array}{c}6 \\
(6 \%)\end{array}$ & 59.040 & 3 & 0.000 \\
\hline 9 & $\begin{array}{l}\text { Motivate teachers and } \\
\text { learners }\end{array}$ & $\begin{array}{c}35 \\
(35 \%)\end{array}$ & $\begin{array}{c}50 \\
(50 \%)\end{array}$ & $\begin{array}{c}0 \\
(0 \%)\end{array}$ & $\begin{array}{c}6 \\
(6 \%)\end{array}$ & $\begin{array}{c}9 \\
9 \%)\end{array}$ & 53.680 & 3 & 0.000 \\
\hline 10 & $\begin{array}{l}\text { Principal striving for board } \\
\text { distinction }\end{array}$ & $\begin{array}{c}35 \\
(35 \%)\end{array}$ & $\begin{array}{c}47 \\
(47 \%)\end{array}$ & $\begin{array}{c}0 \\
(0 \%)\end{array}$ & $\begin{array}{c}15 \\
(15 \%)\end{array}$ & $\begin{array}{c}3 \\
(3 \%)\end{array}$ & 46.720 & 3 & 0.000 \\
\hline
\end{tabular}

Principals' responses about their academic role express that $100 \%$ School head ensure the implementation of best academic principles which were provided by the concerned government. Item 2 depicts that $\mathrm{P}$-value that is 0.000 , means majority school heads supported that they were visiting classrooms and were motivating teachers for using effective teaching methods. The item results showed that the principal role as monitor and examination supervisors were satisfied and they were visiting examination hall and viva centers. They were also very conscious about attending parentteacher meetings where they were briefing about their children's progress reports and also about their other disciplinary issues if any which need their attention.

Table.2. Role of schools Head in school management.

\begin{tabular}{|c|c|c|c|c|c|c|c|c|c|}
\hline S/No & Statements & $\begin{array}{c}\mathbf{S A} \\
f(\%)\end{array}$ & $\underset{f(\%)}{\mathrm{A}}$ & $\begin{array}{l}\text { UD } \\
f(\%)\end{array}$ & $\begin{array}{c}\text { DA } \\
f(\%)\end{array}$ & $\begin{array}{c}\text { S D } \\
f(\%)\end{array}$ & $\begin{array}{l}\text { Chi- } \\
\text { square }\end{array}$ & d.f & $\begin{array}{c}P \text { - } \\
\text { value }\end{array}$ \\
\hline 11 & $\begin{array}{l}\text { Principal try to maintain } \\
\text { school decorum }\end{array}$ & $\begin{array}{c}52 \\
(52 \%)\end{array}$ & $\begin{array}{c}39 \\
39 \%)\end{array}$ & $\begin{array}{c}9 \\
9 \%)\end{array}$ & $\begin{array}{c}0 \\
0 \%)\end{array}$ & $\begin{array}{c}0 \\
0 \%)\end{array}$ & 4.000 & 1 & .046 \\
\hline 12 & $\begin{array}{l}\text { Heads give instructions } \\
\text { to the teachers }\end{array}$ & $\begin{array}{c}45 \\
(45 \%)\end{array}$ & $\begin{array}{c}54 \\
(54 \%)\end{array}$ & $\begin{array}{c}0 \\
(0 \%)\end{array}$ & $\begin{array}{c}1 \\
(1 \%)\end{array}$ & $\begin{array}{c}0 \\
(0 \%)\end{array}$ & 48.260 & 2 & 0.000 \\
\hline 13 & $\begin{array}{l}\text { Principal monitor school } \\
\text { fund }\end{array}$ & $\begin{array}{c}29 \\
(29 \%)\end{array}$ & $\begin{array}{c}51 \\
(51 \%)\end{array}$ & $\begin{array}{c}0 \\
(0 \%)\end{array}$ & $\begin{array}{c}20 \\
(20 \%)\end{array}$ & $\begin{array}{c}0 \\
(0 \%)\end{array}$ & 29.360 & 2 & 0.000 \\
\hline 14 & $\begin{array}{l}\text { School head keep fair } \\
\text { collegiality with staff }\end{array}$ & $\begin{array}{c}40 \\
(40 \%)\end{array}$ & $\begin{array}{c}60 \\
(60 \%)\end{array}$ & $\begin{array}{c}0 \\
(0 \%)\end{array}$ & $\begin{array}{c}0 \\
(0 \%)\end{array}$ & $\begin{array}{c}0 \\
(0 \%)\end{array}$ & 4.000 & 1 & .046 \\
\hline 15 & $\begin{array}{l}\text { School principal ensure } \\
\text { to implement policies }\end{array}$ & $\begin{array}{c}10 \\
(10 \%)\end{array}$ & $\begin{array}{c}31 \\
(31 \%)\end{array}$ & $\begin{array}{c}0 \\
(0 \%)\end{array}$ & $\begin{array}{c}48 \\
(48 \%)\end{array}$ & $\begin{array}{c}11 \\
(11 \%)\end{array}$ & 1.000 & 1 & 0.000 \\
\hline
\end{tabular}

School heads responded regarding their administrative role positively as the P-value of items $11,12,13,14$, and 15 is less than .05 that supported the statements. Data analysis revealed that the schools' heads were in majority agreed that they were exercising best practices to make their concerned schools more effective and best for both teachers and learners. The responses showed that 
they were implementing the policies which were recommended by the government. They also agreed that they were utilizing the school fund according to the need and requirements of the schools and faculty. Their communications with teachers were revealed as satisfactory.

\section{Conclusion}

The outcomes extracted from the data of respondents revealed that the principals who work as a key post at school level were the main figure responsible for the development and maintaining a conducive school climate. The school climate would be more teaching-learning supporting if the will and passion of the school leaders were properly translated and their policies should be implemented in a proper manner and spirit. School heads' major responsibilities were included management tasks, academic element, administration, role as a social activist, engaged with the community, role as a colleague, and work as a caretaker to the established safe climate in schools.

It is also concluded from the study that school and family connection affects learners' educational results and progress in their studies. They showed positive results after establishing strong home school contacts about their academic and other related issues which included the use of polite language at school and in society, personals skills improvement, learning good manners, selfcorrecting, showing personal efficiencies, and courses/syllabus related tasks and results. These connections between school and community provide opportunities for the student to learn a variety of other opportunities in the society which would be helping them in their future life.

Principals' were interested in their job satisfaction, security, availability of all staff including both academic and support, the building of the school, access to the schools, and the availability of the budget for the required tasks.

Principals responded about funds proper utilization that the fund was used clearly and transparently, it was not used by the single authority but it involved school staff, community members, and administration at the same time to avoid any misuse of it. It also revealed that school where the climate was not friendly, the teachers were frustrated and they were not motivated to work due to the discouraging attitude of management. They were also claimed that parents were also not cooperative about their children the poor quality of education. They were not that much responsive regarding their kids' issues or even progress report or diary replies. Parents were not encouraging schools about their children's academic matters replies and other related matters faced to them at schools. It is also identified that the attitude of the parents and teachers was the main cause of school effective climate. The principal should work for the betterment of school and learners. The responsibility of the head should be evaluated based on students' academic progress and their cognitive abilities because if they are weak in academic performance then the school and most particularly its head is responsible and should be accountable to the community.

\section{Discussion}

Principals were the responsible posts at the school level and they bound to work for the betterment of their concerned school. They were satisfied with their jobs, their salaries, their assistant staff, and the powers given to them by the government to be performed and exercised under the rules and regulations. The same findings were found by (Jhonson, 2006) who stated in his research that job satisfaction was directly connected to the school improvement in general and learners' success in particular. When the heads are satisfied and present in their concerned schools the remaining staff and faculty would also be surely present and available and this presence would create a better learning climate in schools for both learners and staff. Staff's attendance and presence would create a productive learning climate and the school's functions would be more healthy and smooth. The social aspect of the school environment was played an important and positive part in creating climate conducive due to the regular and positive relations amongst students, teachers, and principle. Such a relationship developed better understanding amongst the colleagues and community members. Therefore, social contact contributed a lot to the students' learning achievement and motivation. The school heads were also found positive towards co-curricular activities and games. They were actively involved in all types of such out-door and indoor activities which would keep their students physically fit and healthy.

Principals were interested in their concerned schools to discipline and they were found positive about maintaining better school discipline to create a conducive environment and teachers were assigned different duties according to their skills and specialty to help in establishing a better 
learning climate, which was also endorsed by McEwan (2003). Physical facilities of the schools were not up to the needed satisfactory level of the present-day learners and instructors but the principals were committed to utilizing it accordingly for getting the best possible results. Schools' facilitation center's like the canteen and library was not found satisfactory at the secondary level. It also identified by Jhonson (2006) who investigated that the best outcome could be achieved by providing all the needed facilities and learning tools.

\section{Recommendations}

1. It is recommended that the Government establish a mechanism of training for school heads regarding maintaining a conducive environment

2. It is suggested that the education department evaluate principals' various roles for school improvement. A mechanism needs to be developed for it.

3. A calendar for co-curricular activities should be designed and ensure its implementation in schools.

4. The principal should motivate the teachers for their effective duty and the learners for their hard work and best performances.

5. The head of the school should also work as a role model in solving all related problems of both the instructors and the learners and maintain the best climate at school by keeping a

\section{References} balanced workload and unbiased attitude towards all the teachers.

Abdulkareem, A (2011). Management of educational facilities in Nigerian secondary schools. The roles of administrators and inspectors.

Agosiobo, C. (2007) Effective Teaching in Schools: Theory and Practice (2nd ed) Delta Place: Stanley Thorn

Alberta (2009) Principal quality practice guide line: Promoting successful school leadership in Alberta, Alberta Education. Canada.

Aliade,V.H. (2008). The impact of environment on the academic performance of pupils in public primary schools in Gwer local government area of Benue State. Unpublished B.Ed project, Benue State University, Makurdi.

Finn, J. (2002, February). Making sense of continuing and renewed class-size findings and interest. PA

Friedrich, A., Mendez, L. R., \& Mihalas, S. (2010). Gender as a factor in school-based mental health service delivery. School Psychology Review, 39(1), 122-136.

Fullan, M. (2002) The change leader. Educational Leadership, 59(8), pp. 16-20.

Healey, T. (2009). Creating Greatness. Education, Digest, Volume 75 , 30-34.

Hall, D. (2009). Balancing accountability and ethics: A case study of an elementary school principal. University of Texas. Austin, Texas.

Iqbal, M. (2012). Essentials of Educational Administration. Sarhad University of Science and Information Technology, unpublished documents, Peshawar, Pakistan.

Johnson, S.M. (2006). The workplace matters: Teacher quality, retention, and effectiveness. www.nea.org .Retrieved :www.google.com 5-10-2016.

Khan, Nasrullah (2017) Learning Environment Facilitations in Public and Private Universities for Science Students in Khyberpakhtunkhwa, Pakistan. J. Appl. Environ. Biol. Sci., 7(9)17-21, 2017.

Krystal, Fuller (2017) Examination of Parental Involvement in Relation to a Child's Academic Succes, dissertation for the Degree of Doctor of Philosophy.

Lyons (2012). "Do school facilities really impact a child's education?" An introduction to the issues. Schoolfacilities.com/pdf/school

McEwan, E.K.(2003). 10 Traits of highly effective principals: From good to great performance. California: Corwin Press.

Oduwaye, R. O. (2011). Learning Environment and School Managemet Lagos: Scholastic and Allied production Ltd..

Rosenberg, L. (2013). Reflection health means hope: 2013 is the year of the children. The Journal of Behavioral Health Services \& Research, 40(1), 1-4.

Walsh, J. T. (2005). The nature of principal-teacher relationships at North Carolina Title I elementary schools of distinction (Doctoral dissertation, East Carolina University.

Yost, R., (2008). I think I can: Mentoring as means of enhancing teacher efficacy. The Clearing House 75(4), 195-197. Retrieved 10-10-2017. 